\section{Oxidation-reduction Potentials and Capillary Activities of Humic Acids}

Apart from the effects which humic acids have on the physical properties of the soil, such as its structure, permeability and water retention, and through which they influence the growth of plants, it has boen shown that humic acids also have a directly stimulating effect on plant growth ${ }^{1-3}$. In an attempt to trace the cause of this stimulation, Flaig and Otto ${ }^{4}$ investigated the influence of quinones and other oxidation-reduction systems on the growth of plant roots, and found in many instances a favourable effect. Flaig and Beutelspacher ${ }^{5}$ found that in an acid environment and in the presence of nitrogen the $r \mathbf{H}$ value (redox potential) of humic acids decreased. Proper $E_{0}$ values of humic acids, however, have not as yet been published and it was therefore considered to be of interest to study the oxidation-reduction humic acid system in greater detail.

We found that humic acids could be reduced with hydrogen in the presence of colloidal palladium, prepared as described by Gatterman ${ }^{8}$. After reduction of the acids and subsequent removal of the reductant, the reduced acids were titrated in a phosphate buffer at $p H$ 7.0 in a nitrogen atmosphere, with potassium ferricyanide as oxidant. The formal oxidation-reduction potential of the humic acid system was determined from the titration curve. From Fig. 1 it follows that the redox potentials at $p \mathrm{H} 7.0$ of humic acids extracted from the core samples of a tropical sphagnum peat deposit $17 \mathrm{~m}$ deep (for further data see Visser ${ }^{7}$ ) decrease with progressive humification of the peat samples. The mean values of the normal potentials appear to lie between +0.32 and $+0.38 \mathrm{~V}$. In view of these oxidation-reduction properties it also seems possible that apart from their influence on plant growth, which can probably be attributed to an influence on plant respiration, the relatively stable humic acids are playing a part in the oxidation process of soil organic matter.

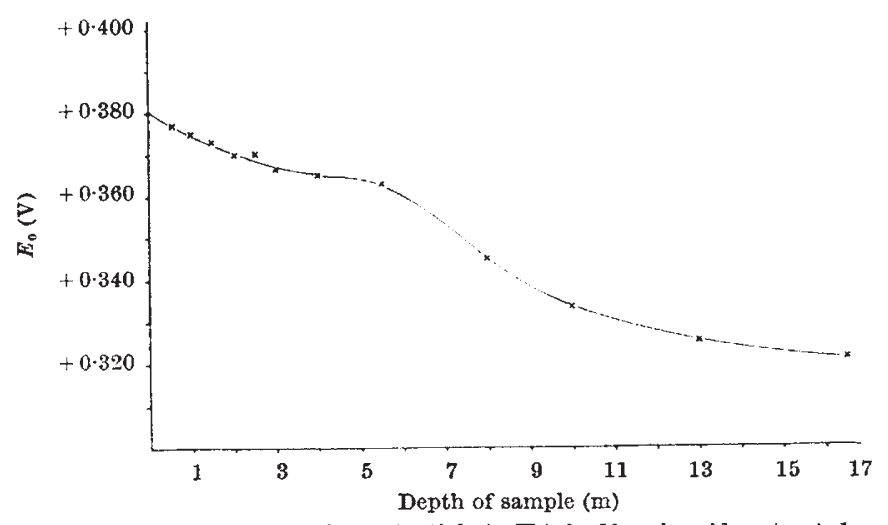

Fig. 1. The formal redox potential at $p$ H $7 \cdot 0$ of humic acids extracted from a tropical sphagnum peat deposit

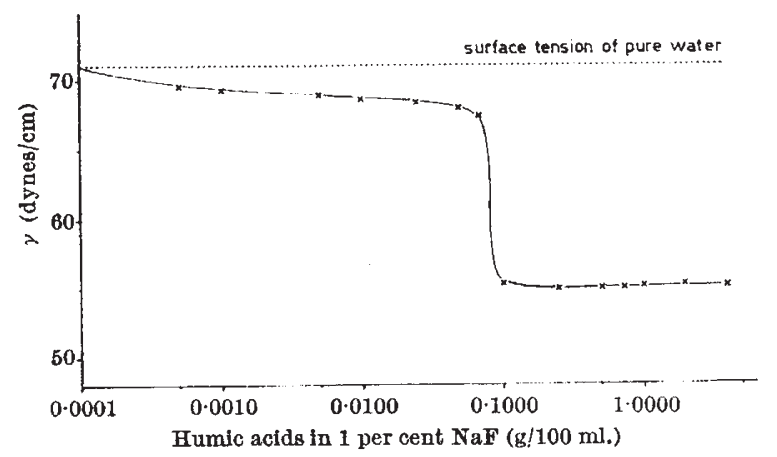

Fig. 2. The surface tension at $30^{\circ} \mathrm{C}$ of humic acid solutions of various concentrations in 1 per cent NaF

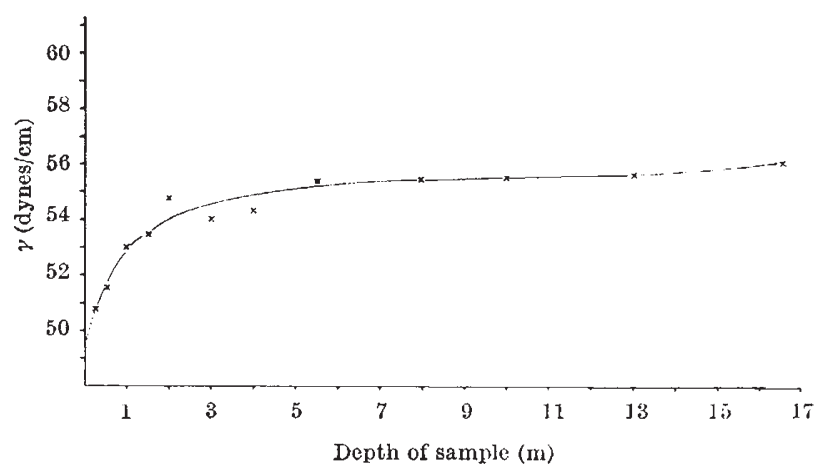

Fig. 3. The surface tension at $30^{\circ} \mathrm{C}$ of 0.2 per cent solutions in 1 per cent $\mathrm{NaF}$ of humic acids extracted from a tropical sphagnum peat deposit

Apart from their effects on plant growth, humic acids are probably also capable of raising the permeability of the cell-protoplasm, which may explain the increased ionic uptakes described by Blagowestschenski and Prosorowskoja $^{8}$ and by Chaminade and Blanchet ${ }^{9}$. For this reason the influence of these acids on the surface tension of water was more closely investigated.

For the measurement of the surface tension of humic acid solutions the acids were dissolved in 1 per cent neutral sodium fluoride. By using Morgan's apparatus ${ }^{10}$ (falling drop method), kept in a thermostatically controlled bath at $30^{\circ} \pm 0.001^{\circ} \mathrm{C}$, it was shown that humic acids behave like typical capillary active substances (Fig. 2). From Fig. 3 it can be deduced that the depression of the surface tension is markedly lower in samples nearer the deeper end of the core than in those nearer the top end, and the capillary activity of humic acids is thus shown to decrease with progressive humification.

Because of their surface-active properties, and of their abundance in soils and in some natural waters, it seems very probable that humic or pre-humic substanees contribute to the foam often observed on swamp waters, and, because of their capillary properties, will contribute to the $p \mathbf{F}$ value of soils.

Department of Zoology,

S. A. VISSER

Makerere University College, Kampala, Uganda.

${ }^{1}$ Barbier, G., Ann. agr., 583 (1986).

${ }^{2}$ Barbier, G., Ann. aør., 36 (1943).

${ }^{3}$ Flaig, W., Landw. Forsch., 8, 133 (1955).

- Flaig, W., and Otto, H, Landwo. Fursch, 3, 66 (1951).

s Flaig, W., and Beutelspacher, H., Landbouwk. Tijdschr., 66, 306 (1954).

- Gatterman, L., Die Praxis des organischen Chemikers (de Gruyter, Berlin, 1943).

${ }^{7}$ Visser, S. A., E. Afr. agric. for. J., 29, No. 3 (in press).

8 Blagowestschenski, A. W., and Prosorowskoja, A. A., Biochem. Z., 282, 99 (1935).

${ }^{9}$ Chaminade, R., and Blanchet, R., C.R. Acad. Sci., Paris, 233, 1486 (1951).

${ }^{10}$ Morgan, J. L. R., J. Amer. Chem. Soc., 33, 349 (1911).

\section{PHYSIOLOGY}

\section{A Non-dialysable, Heat-stabile, Hypertensive Substance in the Serum of Rats}

InCUBATION of rat serum at $37^{\circ} \mathrm{C}$, without any digestion by proteolytic enzymes or change of the $p \mathrm{H}$, effects the liberation of a highly pressure-active substance. This hypertensive effect appears after an incubation of $5 \mathrm{~h}$ and reaches its maximum after $15 \mathrm{~h}$ at $37^{\circ} \mathrm{C}$ (Fig. $1 \mathrm{~A}$ ). The blood pressure of rats nephrectomized $24-48 \mathrm{~h}$ before or after application of a ganglionic blocking agent or infusion of hypotonic glucose is controlled. $0.25 \mathrm{ml}$. of incubated serum given intravenously causes a rise of the blood pressure of about $35 \mathrm{~mm}$ mercury; this equals, in terms of pressor activity, $0.05 \mu \mathrm{g}$ of 'Hypertensin' (CIBA). Infusion of a hypertonic sodium solution diminishes the 